\title{
Bondholder Reorganization of Systemically Important Financial Institutions
}

\author{
Steven Gjerstad
}

Chapman University

June 25, 2017

\begin{abstract}
This paper describes a resolution process for faltering financial firms that quickly allocates losses to bondholders and transfers ownership of the firm to them. This process overcomes the most serious flaws in resolution plans submitted by banks under Dodd-Frank Title I and in the FDIC receivership procedure in Dodd-Frank Title II by restoring the balance sheet of a failing financial institution and immediately replacing the management and board of directors who allowed its demise. In almost all bank failures, this process would eliminate the need for government involvement beyond court certification of the reorganization. The procedure overcomes the serious incentive distortions and inefficiencies that result from bailouts, and avoids the destruction of value and financial market turmoil that would result from the bankruptcies and liquidations that Dodd-Frank requires for distressed and failing banks.
\end{abstract}

\section{Background}

For decades, bailouts have been a standard response when financial firms falter or fail. National treasuries, central banks, and transnational political entities such as the European Union and the International Monetary Fund (IMF) have, due to the absence of alternative resolution mechanisms, taken responsibility for stabilizing financial systems in many countries over the past decades. Over the past several years, political pressures have built in most developed economies to replace bailouts with 'bail-ins', in which a financial firm's creditors will bear responsibility for losses incurred by the bank if it fails. In the U.S. these procedures are mandated in Title I Section 165(d) and Title II (Orderly Liquidation Authority) of the DoddFrank Act. ${ }^{1}$

1 Throughout this document, the Dodd-Frank Wall Street Reform and Consumer Protection Act will be referred to as the Dodd-Frank Act. See https://www.gpo.gov/fdsys/pkg/BILLS-111hr4173enr/pdf/BILLS-111hr4173enr.pdf. 
Although the Dodd-Frank Act is intended to eliminate bailouts, the resolution procedures adopted in it have many of the same flaws that led financial markets to freeze when Lehman Brothers failed and other financial institutions were bailed out in 2008. Title I of the DoddFrank Act requires each systemically important bank to develop detailed plans that specify procedures for its own resolution if it is about to collapse. ${ }^{2}$ The resolution strategies submitted to the Federal Reserve and the FDIC to date rely primarily on either (1) a holding company that will sell some of its subsidiaries to recapitalize the remaining entities while the holding company itself files for bankruptcy protection or (2) a "bridge bank" that will receive the high-quality assets of the failing firm and most of its liabilities, leaving some impaired assets and most longterm debt behind when the bank enters bankruptcy. If the resolution process devised by the company in compliance with Title I Section 165(d) is not implemented successfully and in a timely manner, Title II requires the FDIC to take control of the firm in receivership. ${ }^{3}$ The receivership process described in Title II confers almost unlimited authority on the government appointed trustees in the event that the voluntary resolution process fails. ${ }^{4}$ Criticism has been leveled at the Dodd-Frank for its harshness ${ }^{5}$ and for its subversion of constitutionally guaranteed protections. ${ }^{6}$ Other legal arguments could be mounted against Dodd-Frank, such as those developed in Hamburger (2014) and in Lawson (2015) to address the expansive authority of

${ }^{2}$ See Title I, Section 165 (d) and the records of the public submissions by banks and the responses from the Federal Reserve and the FDIC at https://www.federalreserve.gov/bankinforeg/resolution-plans.htm. See Lee (2015) for analysis of the banks' resolution plans, especially pp. 464 - 486 which describe the adoption of the holding company and bridge bank approaches (jointly known as the single-point-of-entry or SPOE approach).

3 Even the FDIC has sought to avoid the path of liquidation, with most of its efforts directed toward review and assessment of the banks' Title I resolution plans. See Lee (2015, pp. 476-78) for discussion of the pivot by the FDIC from Title II liquidation toward Title I resolution planning.

4 McDermott and Turetsky (2011, p. 412) describe the extent of the receiver's control. "Once the FDIC is appointed receiver of a covered financial company, it assumes virtually complete control over the company and the receivership process. The perfunctory role of the courts in the core receivership process ends, and there are limited avenues for challenging the various ancillary decisions that the FDIC may make in pursuing the liquidation."

5 McDermott and Turetsky (2011, p. 404) argue that "the provisions of the Act and the powers delegated to the FDIC and other government authorities may be draconian when implemented. The right to decide whether to initiate receivership proceedings is vested in government authorities, not in financial companies' boards, management, or stakeholders, and is subject only to very limited judicial review that is highly deferential to such authorities."

${ }^{6}$ Merrill and Merrill (2104) argue that Dodd-Frank Title II violates the due process clause in the 5th amendment and subverts judicial review in Article III of the constitution, among other issues. 
administrative agencies. ${ }^{7}$ The legal arguments against Dodd-Frank are worth pursuing in their own right, but the argument put forth and emphasized in this paper is that the Dodd-Frank procedures impose unnecessary administrative oversight and authority in the resolution of distressed financial firms: a simpler, less disruptive, more transparent market-oriented process can be implemented that defines and respects rights of the firms' creditors.

One of the serious flaws of the Dodd-Frank Act is that, unlike the bankruptcy code, similarly situated creditors will not necessarily be treated equally, under the banks' own resolution plans or in FDIC receivership. When a bank or the FDIC creates a bridge bank and places assets and some liabilities into it, the creditors whose claims are moved to the successor bank or bridge bank will have claims on a going concern. Effectively, their claims will be protected completely from the consequences of the firm's collapse. The creditors whose claims are left behind in the predecessor bank will have claims that may - like those of the unsecured creditors of Lehman Brothers - incur severe losses. Under Title I resolution plans, allocation of claims to the solvent and insolvent entities will be at the discretion of the bank's management and board of directors; in Title II liquidation FDIC receivers will decide, with no avenue for judicial review. The challenge of a reorganization regime for large, systemically important financial firms is to balance the need to maintain the core functions of the firm against the goal of giving equal treatment to similarly situated creditors. Our proposal gives precedence to the objective of maintaining the core functions of the firm, but we also avoid the different treatment of similarly situated creditors by creating a class of creditors who know ex ante that they would be called upon to absorb losses but also know that they will be compensated with ownership of the firm after reorganization.

After a brief review of the balance sheet consequences of an asset collapse, I provide a summary of reorganization bonds, which are a private, market oriented resolution procedure that Vernon Smith and I proposed in a short article in the Wall Street Journal in 2014. Following the

\footnotetext{
7 Hamburger (2014) argues that agencies frequently combine legislative functions in their rulemaking, executive functions in their oversight and enforcement, and judicial functions with their administrative law judges. One of Hamburger's primary arguments is that agencies violate the separation of powers, remove legislative functions from elective bodies, and eliminate judicial review by judges appointed by the elected executive who are confirmed by elected representatives. These arguments clearly have relevance to agency authority in Dodd-Frank, which is extensive and operates explicitly without even the administrative law review provided by other agencies, such as the SEC, the NLRB, the FAA, the EEOC, and dozens of other federal agencies.
} 
description of reorganization bonds, I describe the alternatives to them that have been mandated under Dodd-Frank, along with limitations of those alternatives and how reorganization bonds can overcome the flaws in the Dodd-Frank resolution and liquidation processes.

\section{Asset Collapse and Insolvency}

The diagram on the left side of Figure 1 shows a stylized balance sheet with key asset and liability items for a bank with positive equity. The diagram on the right side of Figure 1 shows the same bank's balance sheet if the value of its assets collapses; in that diagram the bank's equity position disappears and the bank becomes insolvent. A bailout would add cash to the asset side of the balance sheet and more debt to the liability side of the balance sheet, leaving the balance sheet hole the same size. A bailed-out bank typically takes earnings from the healthy portion of its asset portfolio as they come in over the course of many years and moves them to loss reserves so that impaired assets can be removed from the books. During this long period the bank has suppressed earnings to dedicate to dividends, stock buybacks, or organic growth. One consequence of this is that the bank has difficulty finding capital investment, and it will typically deleverage as the only avenue available to it to raise its capital to asset ratio. A method is needed to remove some of the liabilities from the bank's balance sheet. Bankruptcy does that, but at the cost of major disruption to the firm, to financial markets, and to the wider economy. Our proposal achieves the same goal with far less trauma.

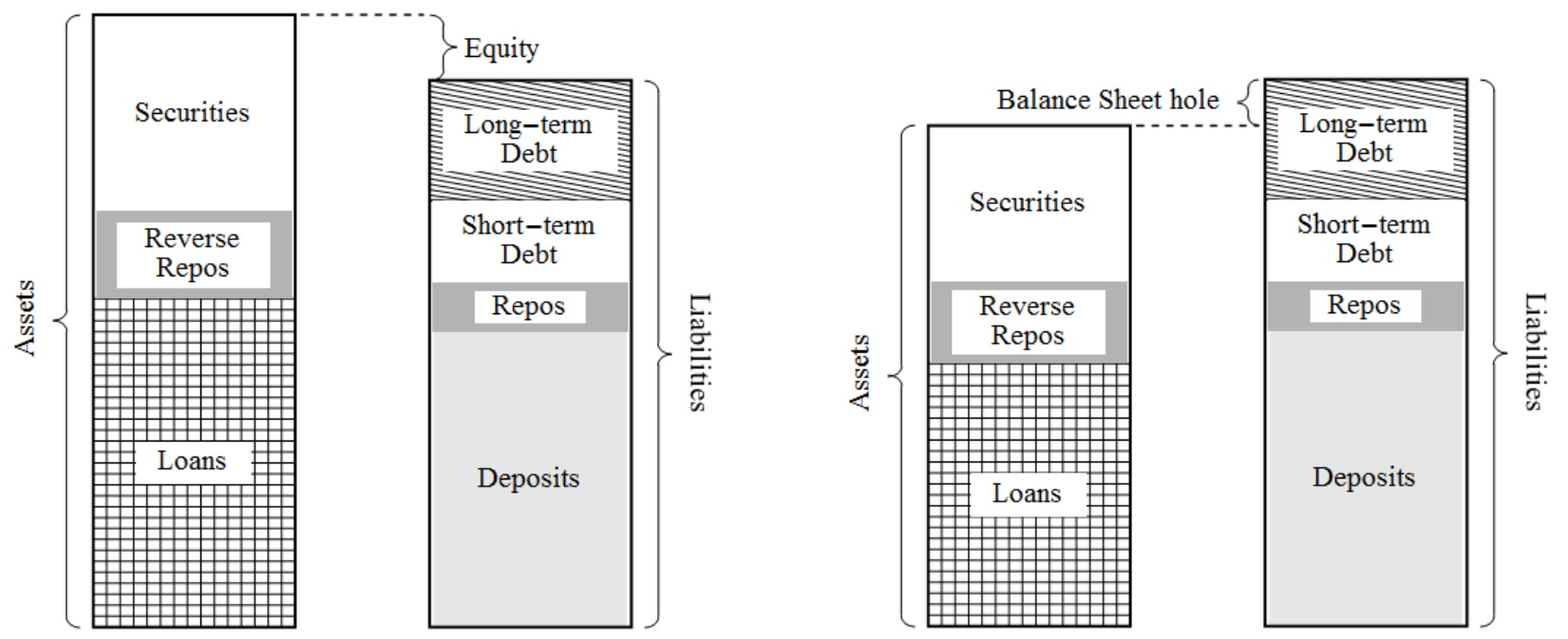

Figure 1: Assets and Liabilities before (left) and after (right) asset values collapse. 


\section{Reorganization bonds}

We propose creation of a class of bonds that sits between equity and all other creditors in the hierarchy of firm obligations. These bonds, which we called 'Reorganization' or ' $R$ ' bonds in Gjerstad and Smith (2014), would be converted to equity immediately upon failure of a firm. ${ }^{8}$ I want to emphasize that Reorganization bonds differ in a crucial respect from contingent convertible bonds, because we propose that ownership and control of the corporation would pass to the bondholders with conversion of the bonds to equity. This is crucial because contingent convertible bonds simply provide the managers who have failed with a new pool of capital, and profits that the firm accrues after conversion would be shared by the owners of the contingent convertible bonds with incumbent shareholders. ${ }^{9}$ Under our proposal, if an asset value collapse causes a firm to run out of equity capital - that is, the firm becomes insolvent - the incumbent equity holders' shares are eliminated, the ' $R$ ' bonds are converted to equity, and the holders of the equity that was created by conversion of the ' $R$ ' bonds become the sole owners of the firm. Figure 2 shows how ' $R$ ' bonds are created from standard long-term debt. Figure 3 shows the effect of eliminating the claims of the original equity holders and converting the ' $R$ ' bonds to a new equity pool. After the ' $\mathrm{R}$ ' bonds are converted, the board of directors selected by the bondholders' committee and the new management team will take control of the firm. Contingent convertible bonds would reward mismanagement and failure with new capital; our proposal circumvents this incentive flaw.

8 By a failure, I mean events like those that precipitated government interventions on behalf of Bear Stearns between March 14 and March 16, 2008, the collapse of Lehman Brothers 6 months later, and the intervention on behalf of AIG on September 16, 2008.

9 Many authors suggest that these bonds could convert to equity if the market capitalization of the firms passes below some threshold, such as 2 percent of the firm's liabilities. When the threshold is crossed, some amount of the bonds would be converted to equity at the market price of equity shares when the threshold was passed. There are at least three significant problems with this approach. One issue is that if the equity price crosses the threshold on its way lower, bond conversion bails out the incumbent shareholders before their shares lose more or all of their value. The second consideration is that these procedures also leave the incumbent management and board in control of the firm. A third problem is that, with the management and board in control of the firm, the new equity holders have minimal protection against the incumbent management and board enriching themselves at the expense of the new equity holders before the new equity holders can wage a fight for control of the firm. For all of these reasons I argue that it would be better to allow the firm to enter a pre-packaged bankruptcy where the bondholders are rewarded with control of the firm. 

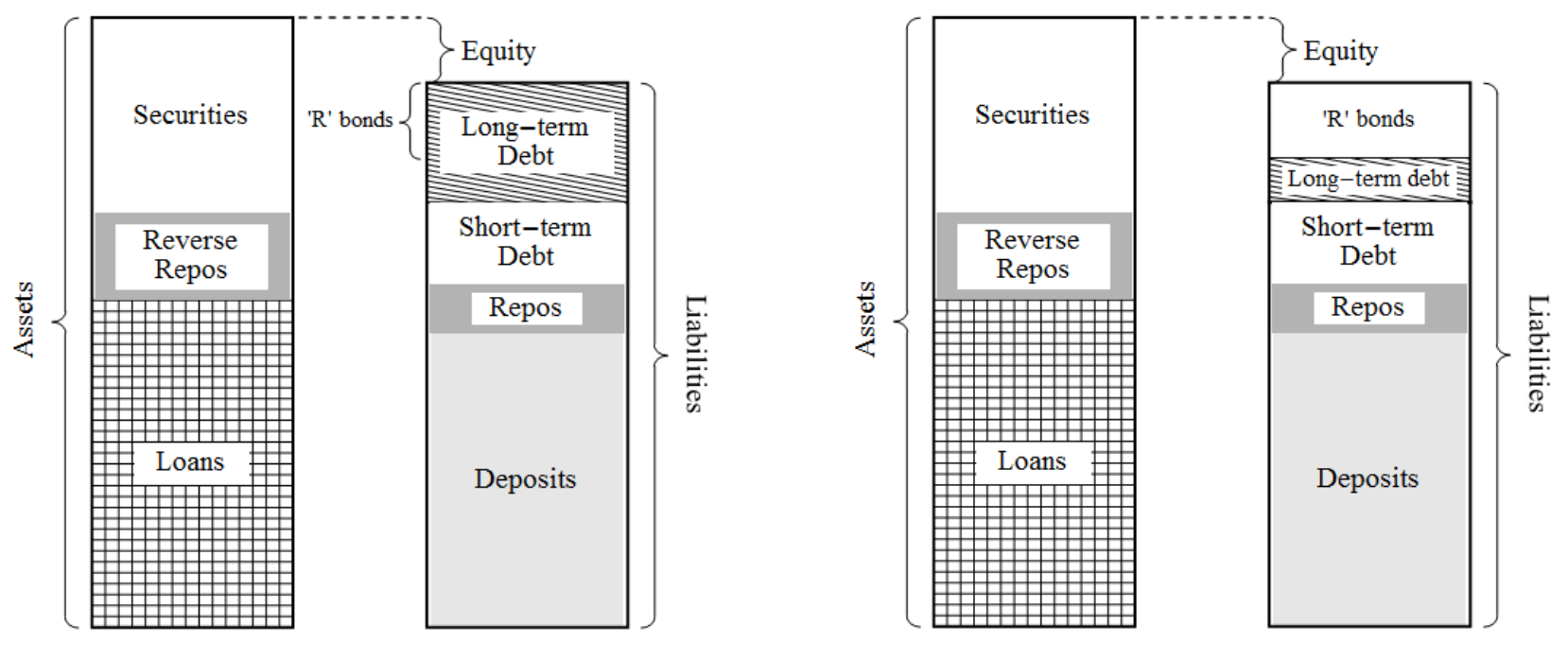

Figure 2: Splitting long-term debt into ' $R$ ' bonds and standard long-term bonds.

With this structure, ' $R$ ' bonds should trade at almost the same price as the bank's standard corporate bonds when the likelihood of failure is near zero, so that a sound bank will face no additional cost of funding with this arrangement. If the bank does become insolvent, then prior equity holder claims are eliminated when ' $R$ ' bonds convert to equity. If losses on assets are less than the sum of the pre-crisis book value of equity and the amount of ' $R$ ' bonds, then the bank's solvency is restored under our procedure and the reorganization will produce a new equity cushion owned exclusively by the investors whose ' $R$ ' bonds were converted. With established criteria that trigger conversion, the ad hoc nature of bailouts, the public funds that support them and their severe incentive distortions can all be eliminated.

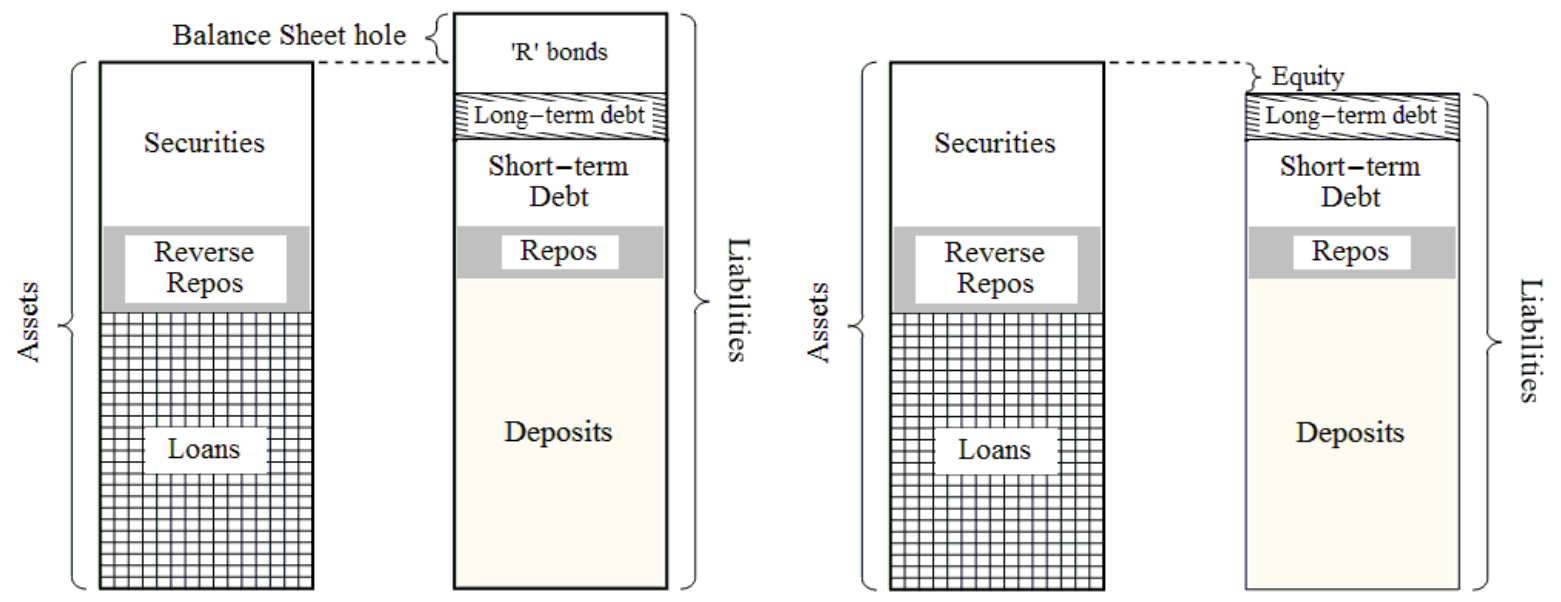

Figure 3: Converting ' $\mathrm{R}$ ' bonds to equity after an asset collapse. 
Conversion of long-term bonds to equity is a key element of our proposal. We propose that, if equity capital is depleted and the firm is on the brink of default, $12 \%$ of the firm's liabilities could be converted into equity capital. Table 1 shows the liabilities of the ten largest banks in the U.S. at the end of 2007; it also shows the amount of long-term debt that each one had outstanding. Each of these firms had between $12.6 \%$ and $26.4 \%$ of their liabilities in the form of long-term bonds, so that each would have been able to meet the threshold for ' $R$ ' bond issuance without a substantial change to its financing costs.

$\begin{array}{lrrrrr} & \begin{array}{c}\text { Total } \\ \text { liabilities }\end{array} & \begin{array}{c}\text { Long-term } \\ \text { debt }\end{array} & \begin{array}{c}\text { Long-term } \\ \text { debt to } \\ \text { liabilities }\end{array} & \begin{array}{c}\text { Book value } \\ \text { of equity }\end{array} & \begin{array}{c}\text { Equity to } \\ \text { liabilities }\end{array} \\ \text { Citigroup } & \$ 2,074.03 & \$ 427.11 & 20.6 \% & \$ 113.60 & 5.5 \% \\ \text { Bank of America } & \$ 1,568.94 & \$ 197.51 & 12.6 \% & \$ 146.80 & 9.4 \% \\ \text { JPMorgan Chase } & \$ 1,438.93 & \$ 199.01 & 13.8 \% & \$ 123.22 & 8.6 \% \\ \text { Goldman Sachs } & \$ 1,076.97 & \$ 164.17 & 15.2 \% & \$ 42.80 & 4.0 \% \\ \text { Morgan Stanley } & \$ 1,014.14 & \$ 190.62 & 18.8 \% & \$ 31.27 & 3.1 \% \\ \text { Merrill Lynch } & \$ 988.12 & \$ 260.97 & 26.4 \% & \$ 31.93 & 3.2 \% \\ \text { Wachovia } & \$ 702.69 & \$ 161.01 & 22.9 \% & \$ 76.87 & 10.9 \% \\ \text { Lehman Brothers } & \$ 668.57 & \$ 123.15 & 18.4 \% & \$ 22.49 & 3.4 \% \\ \text { Wells Fargo } & \$ 527.81 & \$ 99.39 & 18.8 \% & \$ 47.63 & 9.0 \% \\ \text { Bear Stearns } & \$ 383.57 & \$ 68.54 & 17.9 \% & \$ 11.79 & 3.1 \% \\ & \$ 10,443.77 & \$ 1,891 & 18.1 \% & \$ 648.41 & 6.2 \%\end{array}$

Table 1: Long-term debt and equity relative to total liabilities at the end of 2007.

\section{Triggers}

At the end of 2007, the book value of equity capital at Bear Stearns, Lehman Brothers, Merrill Lynch, and Morgan Stanley had fallen to levels just above 3\% of liabilities. (See Table 1, columns 4 and 5.) The Federal Reserve carried out a back-door bailout of Bear Stearns by lending \$28.82 billion to Maiden Lane LLC to purchase impaired Bear Stearns assets in March 2008. Lehman Brothers failed in September 2008. Merrill Lynch was sold to Bank of America with loss guarantees on $\$ 118$ billion of its assets from the Federal Reserve. All three of these firms had inadequate book value of equity capital by the end of 2007 , and it is quite likely that the asset sides of their balance sheets were overstated due to overvalued mortgage securities on 
their books. ${ }^{10}$ By January 8, 2008, the market capitalization of Bear Stearns was only $\$ 8.4$ billion, or about $2.2 \%$ of its liabilities. This is a threshold that clearly requires a contingency plan for reorganization. By July 14, 2008, Lehman Brothers market capitalization had fallen as low as $\$ 8.6$ billion. With $\$ 613$ in liabilities, equity capital had fallen to $1.4 \%$ of liabilities. On the same day, market capitalization of Washington Mutual fell to $\$ 5.5$ billion, or $1.9 \%$ of its liabilities. With these firms in such dire condition, under our proposal bondholders' committees would begin final preparations for a takeover.

\section{Challenges for Resolution Plans and Orderly Liquidation}

Title I Resolution plans have a number of common features. Some of the banks have implemented a holding company structure. Others would utilize a bridge bank in the event of failure. When a holding company is utilized, it would commit substantial resources to its subsidiaries before it enters bankruptcy. The subsidiaries would continue as going concerns until they are sold and the proceeds are returned to the estate of the holding company. A bridge bank would operate similarly, but may be preferred for a firm that has few subsidiaries.

Despite the limitations of the Title I resolution procedures, assessments of the banks plans by the FDIC and the Federal Reserve Board have led to progress on several important problems. Resolution planning has required firms to better align their business operations with their material legal entities, insure that the constituent parts of the firm have access to financial market utilities (especially payment systems and trading and settlement operations), and the banks have implemented service agreements that would provide continued access to information technology support and other critical services to subsidiaries upon a break-up of the firm. Significant progress has also been made to extend the automatic stay in bankruptcies on contracts to include derivatives, futures, and swaps. This makes less likely a repeat of the severe losses precipitated by collateral seizures and sales that followed the Lehman bankruptcy. But the banks' resolution plans depend almost entirely on the optimistic assumption that Global Systemically Important Financial Institutions (G-SIFIs) can resolve themselves and avoid disruption to the U.S. and

\footnotetext{
${ }^{10}$ Washington Mutual provides a good example of this. In its 10-Q filing on June 30, 2008, Washington Mutual had book value of equity capital of $\$ 26.09$ billion (about $9.2 \%$ of its liabilities) but at that time the market value of its equity capital was only $\$ 8.24$ billion (about $2.9 \%$ of equity capital). A closer examination of its balance sheet reveals an extraordinary level of exposure to residential real estate, with $\$ 230.2$ billion in real estate loans and $\$ 19.2$ billion in mortgage-backed securities. Real estate lending amounted to $79 \%$ of assets.
} 
global financial system by breaking themselves apart and selling the pieces - presumably to other G-SIFIs. Of course, financial distress is highly correlated, so many of the largest financial firms will be turning to one another to raise capital. Even if that were possible, the sale of Lehman Brothers investment banking and capital market accounts to Barclays in a Section 363 sale in September 2008 provides insight into the limited capital raised by such sales, and the potential for serious harm to the interests of the seller - in this case the Lehman Brothers estate. According to the Trustee of the estate, James Giddens, Lehman Brothers transferred assets worth approximately $\$ 11,869$ million to Barclays. In addition, Barclays gained over 72,000 customer accounts with assets of $\$ 43,000$ million (about $\$ 600,000$ per account). ${ }^{11}$ Barclays in return paid $\$ 2,438$ million on behalf of Lehman Brothers to third parties.

Title II of the Dodd-Frank Act would transfer control over a faltering financial institution to the Federal Deposit Insurance Corporation (FDIC) as the receiver, charged with liquidation of the firms' assets and payment of claims against the firm. The draconian elements of Title II are well-known ${ }^{12}$, but Title II is also set up to wreak economic havoc, since it relies solely on sales of major business lines and liquidation of the firm. The Lehman Brothers liquidation had catastrophic results for the firms' creditors. In the case of Lehman Brothers, senior bondholders received their first payment in April 2012, three and a half years after the bankruptcy filing. Unsecured creditors received their first distribution in September 2014, six years after the bankruptcy filing. ${ }^{13}$ Fleming and Sarkur (2014) found that, as of March 27, 2014 allowed claims to creditors stood at $\$ 303.6$ billion dollars. With its Twelfth Plan Distribution to Senior Noteholders on April 6, 2017, Wilmington Trust reached a payout of approximately $41.8 \%$ to senior bondholders. ${ }^{14}$ Unsecured creditors have had a comparable payout percentage. Since the estate resolution is nearly complete, losses should end up at approximately $58 \%$ of the $\$ 303.6$

${ }^{11}$ See the State of the Estate, pp. 24 - 25, August 16, 2016 from Hughes Hubbard \& Reed (the law firm of the trustee).

${ }^{12}$ McDermott (2010, p. 2), in an analysis from Skadden, Arps, Slate, Meagher \& Flom LLP argues that "the potential harshness of the Act ultimately may mean that its most salutary effect will be to minimize the circumstances under which it will, in fact, be used." Lee $(2015$, p. 453) points out that "Various critics of Title II maintained that ... Title II would be a non-transparent process and would not be administered according to a clear set of rules and settled precedents in sharp contrast to the Bankruptcy Code. These critics maintained that the [Senate] changes did not alter the fact that the federal government would be choosing which entities to resolve under Title II and which creditors to protect."

${ }^{13}$ See the State of the Estate, pp. 27, op. cit. in footnote 11.

${ }^{14}$ See Wilmington Trust notices to senior noteholders: https://www.wilmingtontrust.com/lehman/notices.html. 
billion in allowed claims, or a loss of approximately $\$ 176.1$ billion to Lehman Brothers creditors. The time frame for payments to creditors, the scale of the losses, and the ex ante lack of clarity regarding how losses would be allocated to creditors could be disastrous for financial markets in future liquidations as they were with Lehman Brothers.

\section{Conclusions}

In this paper I have described a procedure that is capable of addressing the principle challenge of reorganizing failing financial institutions: maintaining the core intermediation and payment functions of the firm, avoiding a fire sale of its assets to cover liabilities, and allocating losses in a manner that is transparent and understood by a firm's creditors ex ante. Many of the challenges facing resolution regimes are obviated by our procedure. The firm remains as a going concern, maintaining both the core functions of the firm and all contractual obligations other than its long-term debt obligations to the holders of the Reorganization Bonds (which are replaced with equity). Concerns that have been raised by the FDIC regarding availability of debtor-in-possession financing are avoided, as are the incentives of foreign regulators and governments to ring-fence the assets of subsidiaries in their jurisdiction. Other concerns with resolution and liquidation regimes are also mitigated. Calabria (2015) points out that "the Treasury ... may have felt that allowing a default on GSE debt would be viewed internationally as the equivalent of a default by the U.S. government." Concerns of this sort may lead regulators and politicians to ignore the law altogether and proceed with a bailout, as they did with the resolution procedures for Fannie Mae and Freddie Mac in 2008, or it may lead to pressures to include some favored creditors of a failing bank in the debts of the bridge bank and less fortunate or less favored creditors in the bankruptcy. The ambiguous status of creditors under both the Title I resolution plans and the Title II liquidation procedures leave either of these possibilities

open. Our procedure, by specifying particular long-term debt for conversion, lessens the pressure for a bailout and eliminates the possibility of favored treatment by government receivers for particular creditors of a failing financial institution.

The procedures could be developed in a new Chapter 14 of the bankruptcy code or in modifications to Chapter 11 for systemically important financial institutions. A great deal of work has been done to plan for the contingency that an important financial firm must enter bankruptcy or be liquidated. It would be good though to avoid those paths with a process that 
maintains all of the functions of a major financial institution without interruption, and prepositions liabilities that can be dedicated to recapitalize a failing financial firm in a manner that is known ex ante to regulators, to the firm's creditors, and to other market participants.

\section{References}

Calabria, Mark (2015). "The Resolution The Resolution of Systemically Important Financial Institutions: Lessons from Fannie and Freddie," Cato Institute Center for Monetary and Financial Alternatives, No. 25. https://object.cato.org/sites/cato.org/files/pubs/pdf/working-paper-25 1.pdf

Fleming, Michael J. amd Asani Sarkur (2014). “The Failure Resolution of Lehman Brothers," Federal Reserve Bank of New York Economic Policy Review, December, pp. 175-205.

Gjerstad, Steven and Vernon L. Smith (2014). "Bonds, Not Bailouts, for Too Big to Fail Banks," Wall Street Journal, August, 12.

Hamburger, Philip (2104). Is Administrative Law Unlawful?, Chicago, Illinois: The University of Chicago Press.

Lawson, Gary (2015). "The Return of the King: The Unsavory Origins of Administrative Law," Texas Law Review, 93:6, pp. 1521-45.

Lee, Paul L. (2015). "Bankruptcy Alternatives to Title II of the Dodd-Frank Act-Part I," The Banking Law Journal, pp. 437-87.

McDermott, Mark A. (2010). "Analysis of the Orderly Liquidation Authority, Title II of the Dodd-Frank Wall Street Reform and Consumer Protection Act," Skadden Arps.

https://www.skadden.com/sites/default/files/publications/FSR_A_Analysis_Orderly_Liquidation_Authority.pdf

McDermott, Mark A. and David M. Turetsky (2011). "Restructuring Large, Systemically-Important, Financial Companies: An Analysis of the Orderly Liquidation Authority, Title II of the Dodd-Frank Wall Street Reform and Consumer Protection Act," American Bankruptcy Institute Law Review, Vol. 19:2, pp. $401-451$.

Merrill, Thomas W. and Margaret L. Merrill (2014). "Dodd-Frank Orderly Liquidation Authority: Too Big for the Constitution?," University of Pennsylvania Law Review, Vol. 164, pp. 165-247.

United States Congress (2010). "Dodd-Frank Wall Street Reform and Consumer Protection Act," Washington D.C.: U.S. Government Publishing Office.

https://www.gpo.gov/fdsys/pkg/PLAW-111publ203/pdf/PLAW-111publ203.pdf 